\title{
Immobilization of Lipase From Azospirillum sp. PRD1 Using Chitosan Alginate as Supporting Agent
}

Zusfahair*, Dian Riana Ningsih, Santi Nurhandayani, Puji Lestari, and Dadan Hermawan

Department of Chemistry, Faculty of Science and Engineering, Jenderal Soedirman University, 53123 Purwokerto, Indonesia. *Corresponding Author: zusfahair@gmail.com

\section{Article history :}

Received 12 August 2014

Revised 7 September 2014

Accepted 12 November 2014

Available online 25 November 2014

GRAPHICAL ABSTRACT

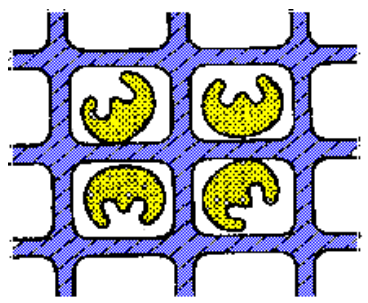

\begin{abstract}
Immobilization of lipase from Azospirillum sp. PRD1 bacteria with trapping method using chitosan alginate has been successfully performed in this study. The study was started by manufacture of the inoculum, followed by the production of enzymes and extraction with centrifugation method. The crude extract obtained was fractionated using ammonium sulphate and the $60 \%$ fraction was used for the immobilization of enzymes and determination of its molecular weight. The preparation of chitosan alginate beads were performed using several variations that are chitosan concentration, enzyme volume: chitosan alginate ratio, incubation time and the concentration of TPP. The activity of lipase beads formed was tested using titrimetric methods. The results showed that the fraction of $60 \%$ was more pure than the crude extract. The chitosan used has de-acetylation degree of $74.57 \%$. The synthesis of the immobilized lipase beads was optimum at $8.5 \%$ chitosan concentration, ratio of enzyme:chitosan alginate of $1: 10,150$ min incubation time and $2 \%$ TPP concentration with activity of $90 \mathrm{U} / \mathrm{mL}$.
\end{abstract}

Keywords: Azozpirillum sp. PRD1, Chitosan alginate, Immobilization, Lipase, Supporting agent

(C) 2014 Penerbit UTM Press. All rights reserved http://dx.doi.org/10.11113/mjfas.v10n4.276

\section{INTRODUCTION}

Lipase utilization for domestic industry is limited by its high price [1]. One way to overcome this limitation is to use native microbial lipases from Indonesia, such as from Azospirillum sp. PRD1 bacteria. Lipase from Azospirillum sp. PRD1 bacteria has specific activity of 3324 units $/ \mathrm{mg}$ protein, optimum temperature of $42{ }^{\circ} \mathrm{C}$ and optimum $\mathrm{pH} 7$ [2-3]. These conditions correspond to the use of lipase as an industrial biocatalyst in the hydrolysis of oil into fatty acids for minimizing thermal degradation products. Nowadays, the hydrolysis of oils into fatty acids in industrial processes is carried out at a temperature of $250{ }^{\circ} \mathrm{C}$, so that the fatty acid products produced is dark colored and side reactions can occur [4]. Therefore, the uses of lipase as biocatalyst for enzymatic oil hydrolysis into fatty acids provide better opportunities.

The utilization of enzyme as biocatalyst in industry is usually in the form of immobilized enzyme. Lipase immobilization technique of Azospirillum sp. PRD1 that will be used in this research is trapping method because it is easy, simple, and relatively cheap. The decrease in activity is also smaller compared to the binding method. The supporting material used was chitosan alginate.

Alginate is a natural heteropolysaccharide with a linear chain of D-mannuronic acid and L-guluronic acid that derived from brown seaweed (Phaeophycea). Alginate has negative charge and will form gel with divalent cations such as calcium [5]. The utilization of calcium alginate as an immobilization support material is because it has several advantages such as non- toxic, relatively inexpensive, and easy to do. Chitosan is a cationic polysaccharide with a linear chain of D-glucosamine and 2-deoxy-2-acetamidoD-glucosamine which can be obtained from shrimp waste [6-7]. Chitosan has several favorable properties including hydrophilic, biocompatible, biodegradable, antibacterial properties and possess great affinity to enzyme. The use of chitosan as a supporting material on enzyme immobilization process has several advantages as it is easy to get, easy isolation procedure, non-toxic and harmless [8]. The combination of chitosan and alginate can avoid the leakage of enzymes, therefore increasing its stability [9].

In the immobilization process, in order to produce high activity immobilized lipase beads, it is necessary to perform optimization of the optimum conditions which include: matrix concentration, enzyme volume, contact time and concentration of TPP. The purpose of this study is to determine the optimization on the synthesis of immobilized lipase from Azospirillum sp. PRD1 bacteria using chitosan alginate matrix.

\section{EXPERIMENTS}

\subsection{Materials}

Materials used in this study are purely isolates of Azospirillum sp. PRD1 collection of Laboratory of Microbiology- Faculty of Biology Unsoed, chitosan, 
soybean oil, instant NA (Nutrient Agar) medium, instant NB (Nutrient Broth) medium, aquades, ammonium sulphate, glycerol, $\mathrm{NaCl}$, cellophane, $\mathrm{Ba}(\mathrm{OH})_{2}$, Arabic gum, phosphate buffer $\mathrm{pH} \mathrm{7,} \mathrm{acetone,} \mathrm{ethanol,} \mathrm{alcohol,}$ $\mathrm{NaOH}$, Tri-polyphosphate (TPP), acetic acid, phenolphthalein indicator, polyacrylamide, tris-buffer $\mathrm{pH}$ 8.8, SDS (sodium dodecyl sulphate), TEMED ((N,N,N',N'tetramethyl ethylenediamine), APS (ammonium persulphate), glycine, DTT (ditiotreitol), mercapto ethanol, bromphenol blue, glycerin, methanol, and commasie blue. Tools. Petri dish, reagent bottles, capped test tubes, Erlenmeyer flask, ose-needle, "Hanna Instruments"pH meter, micro burette, Eppendorf tubes, stative, automatic micro pipette, "T 120" centrifuge, Memmert incubator shaker, autoclave, hot plate/stirrer, separating funnel, a set of dialysis tools, 8201PC spectrophotometer FT-IR, and a set of SDS PAGE electrophoresis instruments.

\subsection{Lipase Production.}

Lipase production was started with the rejuvenation of the bacteria. A stock isolate of pure Azospirillum sp. PRD1 in glycerol was rejuvenated in the NA slant medium and was incubated for $2 \times 24$ hours at room temperature. Azospirillum sp. PRD1 Bacteria rejuvenation resulted was then inoculated into NB (Nutrient Broth) medium and was incubated on a Kottermann shaker incubator with speed scale at 7 at room temperature for 10 hours. As much as $20 \%(\mathrm{v} / \mathrm{v})$ of the inoculum was transferred into an enzyme production medium (NB medium with inducers of $1 \%$ soybean oil) and was further incubated in a Kottermann incubator shaker with speed scale at 7 at room temperature for 14 hours. The liquid medium was then centrifuged using a cold centrifuge (6000 rpm, $4{ }^{\circ} \mathrm{C}, 10 \mathrm{~min}$.) to separate the cell debris and the supernatant. The supernatant obtained is the crude extract of lipase. Lipase activity of the crude extract was measured using the titrimetric method adapted from Prazeres et al. [9]. The substrate used was $25 \%$ soybean oil emulsion in a $10 \%$ solution of arabic gum and $50 \mathrm{mM}$ phosphate buffer $\mathrm{pH} 7$ with a ratio of 1:2:1 which was mixed until homogeneous. Enzyme reaction mixture consisted of $2.5 \mathrm{ml}$ of soybean oil emulsion, which was incubated for 5 minutes at $35{ }^{\circ} \mathrm{C}$, added with $0.1 \mathrm{~mL}$ of enzyme before incubated for 30 minutes. The reaction was stopped by the addition $1.25 \mathrm{~mL}$ of acetone: ethanol $(1: 1)$ then was titrated using $\mathrm{NaOH} 0.05$ M. As control the addition of the enzyme performed after the addition of acetone: ethanol (1:1). Lipase activity was determined from the volume of $\mathrm{NaOH}$ required to titrate the sample reduced by the volume of $\mathrm{NaOH}$ required for titration control. One unit (U) of lipase activity is defined as the amount of enzyme that produces $1 \mu$ moles free fatty acid per minute. Unit of enzyme activity is calculated by:

$\mathrm{U}=(\mathrm{V}$ NaOH sample $-\mathrm{V} \mathrm{NaOH}$ control $) \times(100 / \mathrm{V}$ enzyme $)$

Lipase crude extract was concentrated by adding ammonium sulphate salt with $60 \%$ saturation continued by stirring using a magnetic stirrer at $4{ }^{\circ} \mathrm{C}$ until the extract was dissolved, then centrifuged in a cold centrifuge $(4000 \mathrm{rpm}$, $4^{\circ} \mathrm{C}, 10 \mathrm{~min}$.). The obtained precipitate was dissolved in 5 $\mathrm{mL}$ of $1 \%(\mathrm{w} / \mathrm{v}) \mathrm{NaCl}$ and then was dialyzed using a cellophane bag. Dialysis performed at $4^{\circ} \mathrm{C}$ while stirring in a magnetic stirrer. The dialysate used was distilled water. Dialysis was performed by replacing the dialysate every 30 min. Each dialysate obtained was tested with a solution of $\mathrm{Ba}(\mathrm{OH})_{2}$ to determine whether there was salt. Dialysis was stopped when the dialysate does not contain salt marked by the absence of precipitate when tested with a solution of $\mathrm{Ba}(\mathrm{OH})_{2}$. The result of dialysis was furthermore diluted with $1 \% \mathrm{NaCl}$ to $30 \mathrm{~mL}$, and then the activity and the molecular weight was determined using SDS PAGE electrophoresis $12 \%$ using the previous method [10]. Lipase obtained was then immobilized using chitosan alginate matrix.

\subsection{Lipase Immobilization.}

Chitosan used in the immobilization process is characterized by FTIR. Determination of the optimum concentration of chitosan in the manufacture of immobilized lipase beads. Chitosan with various concentration of $7.5 \% ; 8 \%, 8.5 \%, 9 \%$ and $9.5 \%(\mathrm{w} / \mathrm{v})$ were dissolved in $1 \%$ Acetic acid, at a temperature of $55^{\circ} \mathrm{C}$ and stirred until dissolved. Each chitosan solution was added with $1 \mathrm{~mL}$ of $1 \%(\mathrm{w} / \mathrm{v})$ alginate solution (in $0.1 \mathrm{M}$ phosphate buffer $\mathrm{pH} \mathrm{7)}$ and $1 \mathrm{ml}$ of enzyme fraction $60 \%$ (ratio of volume enzyme: solution of chitosan + alginate solution 1:10). The solution was stirred until homogeneous before dripped into a $2 \%$ solution of TPP, allowed to stand for $120 \mathrm{~min}$ and further filtered. The activity of chitosan alginate beads formed was tested. Alginate chitosan beads having the highest activity value was subsequently used for the volume variation of the enzyme beads preparation.

Determination of the optimum volume of the enzyme on the manufacture of immobilized lipase beads. The optimum concentration of chitosan and alginate solution $1 \%$ (in $0.1 \mathrm{M}$ of phosphate buffer $\mathrm{pH} 7$ ) was added to the enzyme under enzyme: chitosan alginate volume ratio of: $1: 8,1: 9 ; 1: 10 ; 1: 11,1: 12$. The solution was stirred until homogeneous before dripped into a solution of $2 \%$ TPP and allowed to stand for $120 \mathrm{~min}$ and furthermore filtered. The activity of Chitosan alginate beads formed was tested. Chitosan alginate beads with the highest activity value were used for the variation of the contact time.

Determination of optimum contact time on the manufacture of immobilized lipase beads. Chitosan with optimum concentration was added with $1 \mathrm{~mL}$ of $1 \%$ alginate solution (in $0.1 \mathrm{M}$ phosphate buffer $\mathrm{pH} 7$ ) and $1 \mathrm{ml}$ of $60 \%$ enzyme fraction at the optimum ratio is stirred until homogeneous before dripped into a solution of $2 \%$ TPP, allowed to stand by contact time variation $60^{\prime} ; 90^{\prime} ; 120^{\prime}$; $150^{\prime} ; 180^{\prime} ; 210^{\prime}$ and then filtered. The activity of chitosan Alginate beads formed was tested. Chitosan alginate beads 
with the highest activity value were used for the variation of concentration of TPP.

Determination of the optimum concentration of TPP in the manufacture of immobilized lipase beads. The solution at the optimum conditions obtained from above procedures were subsequently dripped into a solution of the TPP with the variation of the concentration of $1 \%, 1.5 \%$, $2 \%, 2.5 \%, 3 \%$ before let to stand at 150 minutes and then filtered. The activity of the chitosan Alginate beads formed was tested.

\section{RESULTS AND DISCUSSION}

\subsection{Lipase Production from Bacteria Azospirillum sp. PRD1.}

Azospirillum sp. PRD1 bacteria was inoculated into NB (Nutrient Broth) medium and incubated on a Kottermann shaker incubator with 7 speed scale at room temperature for 10 hours. As much as $20 \%$ of the inoculum was transferred into the enzyme production medium (NB medium with inducers of soybean oil 1\%) and was incubated in a Kottermann incubator shaker with 7 speed scale at room temperature for 15 hours. The liquid medium was then centrifuged using a cold centrifuge $(6000 \mathrm{rpm}, 4$ ${ }^{\circ} \mathrm{C}, 10 \mathrm{~min}$.) to separate the cell debris and the supernatant. The supernatant obtained was a crude extract of lipase. Lipase crude extract was further fractionated with ammonium sulphate, followed by dialysis to obtain a $60 \%$ fraction. Lipase crude extract and the fractionation results were also analyzed using 60\% SDS PAGE electrophoresis. Electrophoresis results can be seen in Figure 1. Figure 1 shows that the lipase crude extract is found in many protein bands. The lipase fractionation results are shown 2 bands i.e. less than than 14,400 Dalton and 66,200 Dalton molecular weight, respectively. Based on the previous study [11], the lipase has 65,000 Dalton molecular weight.

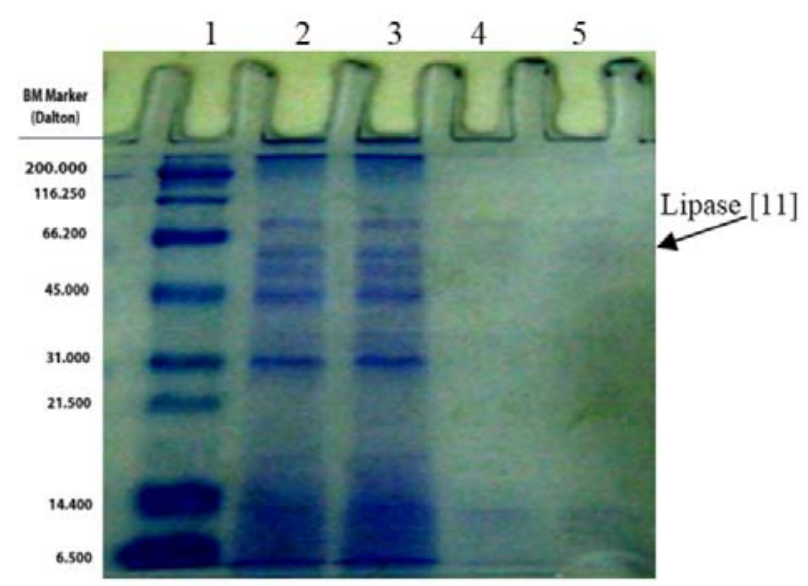

Figure 1. The results of electrophoresis of lipase crude extract and $60 \%$ fractionation results. 1: Marker; 2 and 3: lipase crude extract; 4 and 5: $60 \%$ lipase fractionation results.

\subsection{Determination of Degree of Deacetylation of Chitosan}

The study begins by determining the quality of chitosan used by measuring the degree of de-acetylation (DD) using IR spectroscopy method. DD shows the percentage of acetyl groups in chitosan lost from the chitin to produce chitosan. The use of DD as quality parameters of chitosan is due to the presence of acetyl groups in chitosan that will decrease the effectiveness of chitosan. A large concentration of acetyl groups in chitosan can lead to weak interaction between the ions and hydrogen bonds that ultimately affect the effectiveness of chitosan. Chitosan is produced in high purity when the acetyl group content is low and this is indicated by a high DD value of chitosan. The analysis showed that the chitosan used in this study has a deacetylation degree (DD) value of $74.57 \%$ (Figure 2). According to previous study [10], chitin with DD ranged from $70 \%-90 \%$ is considered as pure chitosan. This suggests that the chitosan used in this study has met the standard DD of chitosan products.

Further step is immobilization of lipase using chitosan alginate thus obtained immobilized lipase beads. To get immobilized lipase beads with high activity, an optimization is carried out.

\subsection{Lipase immobilization using alginate chitosan.}

Chitosan can be mixed with alginate to form a mixture of chitosan-alginate [8]. The alginate mixed with chitosan will cause ionic interaction between the alginate carboxyl group and the chitosan amino terminal residues forming polyelectrolyte complexes [12]. The complex is not soluble in the presence of TPP, thus stabilize the gel. The use of chitosan and alginate as enzymes immobilization matrix have advantages and disadvantages. But the shortage that occurs can be minimized with the use of both the matrix which works synergistically. To get immobilized lipase beads with high activity, variations of alginate chitosan concentration, enzyme volume, contact time and concentration of TPP were performed.

\subsection{Variations in the concentration of chitosan in the manufacture of immobilized lipase.}

The chitosan concentrations used were $7.5,8.0,8.5$, 9.0 , and $9.5 \%$. Onto each was then added with a $1 \%$ solution of alginate and $60 \%$ enzyme fraction (ratio of the volume of the enzyme solution with a solution of chitosan + alginate of $1: 10)$. The solution was dripped on a $2 \%$ solution of TPP and allowed to stand for $120 \mathrm{~min}$ and filtered. Chitosan alginate beads formed was tested for its activities. Results showed that lipase immobilizing activity is low at the chitosan concentration of $7.5 \%$ (data not shown). This is because the formed beads are fragile and has larger pore size causing enzyme to exit easily from the cavity. Increasing the concentration of chitosan give result to more compact beads formed, so that the activity 
increases and reaches optimum at chitosan concentration of $8.5 \%$. This is due to the size of the pore of formed beads are also getting smaller and denser so it can withstand the enzyme out of the beads, but are able to contact with the substrate. The smaller the pore size causing it is not easy for enzymes to get out of the beads. The Immobilized lipase activity drops with increasing concentrations of chitosan. This is due to the resulting mixture that is denser so that the beads formed are trailing because it is difficult to be dripped into solution of TPP. Denser mixture of lipase beads having a smaller pore size, and affect the difficulty of interaction between enzyme and the substrate.

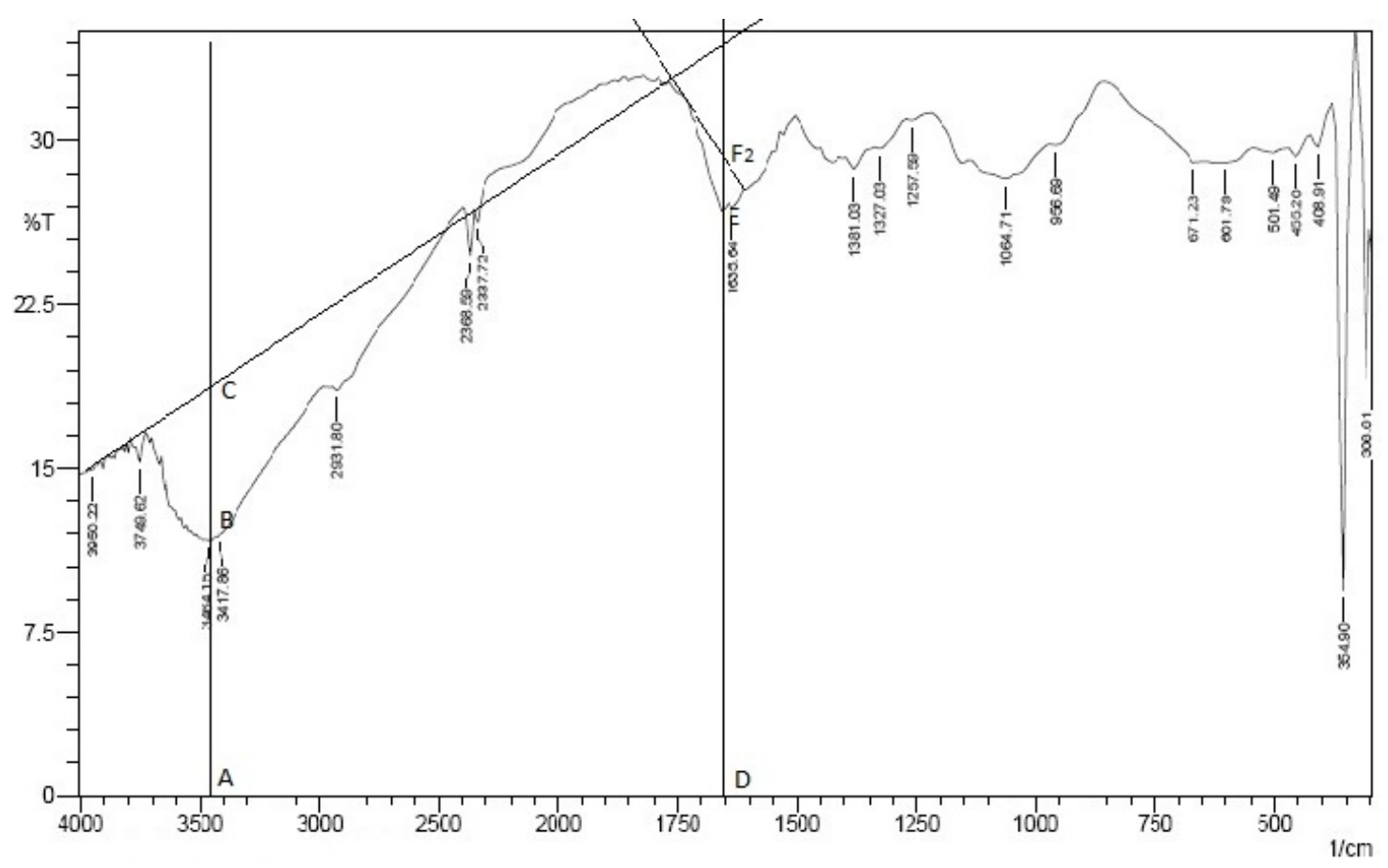

Figure 2. IR spectra of chitosan.

\subsection{Variations in the enzyme volume in the making of immobilized lipase.}

The variation of volume of $60 \%$ fraction of enzyme proportion between enzymes: alginate chitosan are 1:8; 1:9; $1: 10 ; 1: 11$; and $1: 12$, performed at $8.5 \%$ chitosan concentration, TPP concentration of $2 \%$ and contact time of 120 minutes. Results showed that the activity of the immobilized lipase was initially low (Figure 3 ).

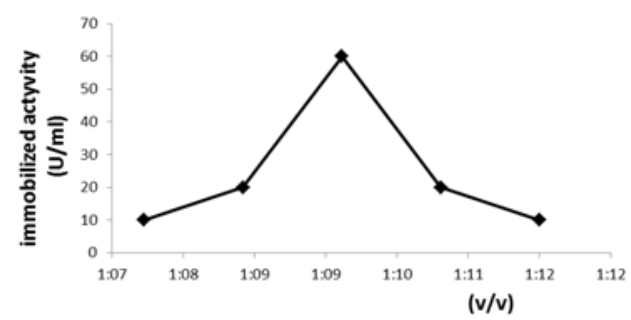

Figure 3. Effect of variation of volume on the activity of immobilized lipase from bacteria Azospirillum sp. PRD1

This is because the composition of the enzyme is not in accordance with chitosan alginate so that the formed beads are fragile. In volume ratio enzyme: chitosan alginate used subsequently, the optimum composition is at the ratio of $1: 10$. This shows the resulting beads become compact with a smaller pore size that makes it easy for substrate to enter and exit the beads. In volume ratio enzyme: chitosan alginate of 1: 11 and 1: 12, the less volume of enzyme used causing the enzyme less binds to the substrate. This condition leads to a decrease in enzyme activity.

\subsection{Variation of incubation time on the making of the immobilized lipase}

The study was conducted on chitosan concentration of $8.5 \%$, volume ratio of enzyme: chitosan alginate 1:10, $2 \% \mathrm{CaCl}_{2}$ concentration with a variation of the contact time between lipase immobilized beads with $\mathrm{CaCl}_{2}$ solution are: $60,90,120,150,180$, and 210 minutes. The interaction of chitosan with alginate resulted in the formation of polyelectrolyte complexes according to the following equation [13]:

$$
\sim \mathrm{COO}^{-} \mathrm{Na}^{+}+\mathrm{Cl}^{-+} \mathrm{NH}_{3} \sim \quad \rightarrow \quad \mathrm{COO}^{-+} \mathrm{NH}_{3} \sim+\mathrm{NaCl}
$$


This interaction is reinforced by the TPP as the crosslinker. Results show that the activity of the immobilized lipase is initially low (Figure 4). This is because the small amount of crosslink formed therefore the bead pores are large.

Larger pore size beads cause the enzyme to exit out of the beads. Immobilized lipase activity was increasing slowly with increasing contact time and rose significantly at 150 minutes of contact time, before dropped significantly. The longer contact time between the immobilized lipase beads with TPP solution causing the crosslink between alginate chitosan with TPP increase. This causes the formed beads denser to produce pores that facilitate substrate interaction with the enzyme. Increasing contact time would further decrease the activity of the enzyme. This is due to the possibility of enzyme out of the beads due to the mechanical movement of the shaker incubator, although the data of proteins that pass in and out of beads was not observed.

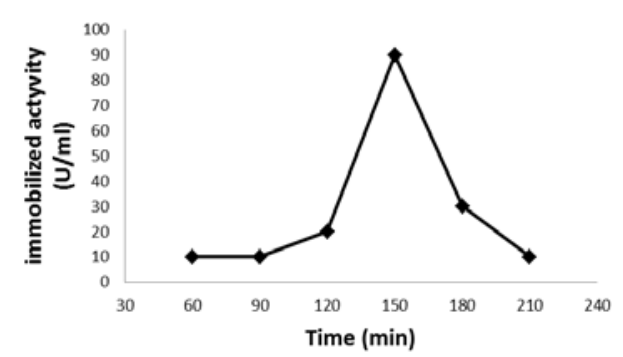

Figure 4. The effect of variation of contact time on the activity of immobilized lipase from bacteria Azospirillum sp. PRD1

\subsection{Variation in the concentration of TPP in the manufacture of immobilized lipase.}

The study was conducted on chitosan concentration of $8.5 \%$, the volume ratio of enzyme:chitosan alginate (1: 10), 150 minutes contact time with the variation of the concentration of TPP from 1, 1.5, 2, 2.5, and 3\%. Results show that the activity of the immobilized lipase was initially low and reached the peak at the concentration of $2 \%$. Addition of TPP concentration further decreased the enzyme activity significantly (Figure 5). More crosslink compounds used the harder beads formed so that the beads pores are getting smaller.

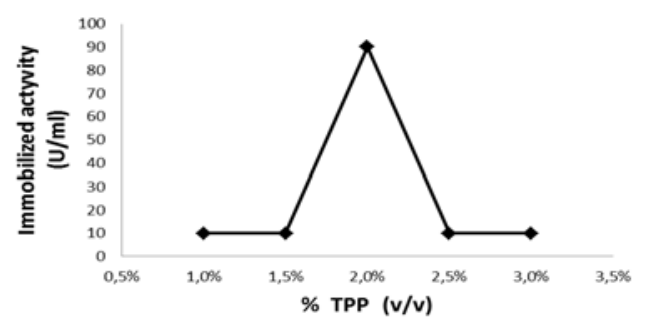

Figure 5. The effect of TPP concentration variation on the activity of immobilized lipase from Azospirillum sp. PRD1 bacteria.

\section{CONCLUSION}

Lipase from Azospirillum sp. PRD1 bacteria fractionated with $60 \%$ saturation level was more pure than the lipase crude extract. Chitosan used as the supporting matrix in the immobilization process has DD value of $74.57 \%$. The manufacture of immobilized lipase beads reach optimum condition at $8.5 \%$ chitosan concentration, ratio of enzyme: chitosan alginate $1: 10,150$ minutes incubation time and 2\% TPP concentration with the activity value of $90 \mathrm{U} / \mathrm{mL}$.

\section{ACKNOWLEDGEMENTS}

The financial support provided by the Directorat General of Higher Education, Ministry of National Education and Culture Indonesia through the Competitive Grant DIPA UNSOED No 64/UN23.10/PN/2013 is gratefully acknowledged.

\section{REFERENCES}

[1] Wulan, P.D.K., Rejoso, M.T., and Hermansyah, H., Hydrolysis of Olive oil Immobilized by Adsorption, Department of Chemical Engineering, Faculty of Engineering, University of Indonesia, Depok, 2007.

[2] Handayani, S.N, Lestari, P., Oedjijono, Raharjo, T.J., and Matsjeh, S. Proceeding of National Seminar of Chemistry and Chemistry Education, UNDIP. Semarang, 2010.

[3] Handayani, S.N., Lestari, P., Oedjijono, Raharjo, T.J., and Matsjeh, S., Sci. J. Mol. 6 (2011) 2.

[4] Serri, N.A., Kamarurudin, A.H., and Rahaman, S.N.A., J. Phys. Sci. Vol. 19 (2008) 79.

[5] Gulay, S., Immobilization Of Thermophilic Recombinant Esterase Enzyme By Entrapment In Coated Ca-Alginate Beads. Thesis, İzmir Institute Of Technology, 2009.

[6] Kurniasih, M., and Kartika, D., J. Inov. Unsoed. 5 (2011) No. 1. 42.

[7] Nasratun, M., Said, H.A., Noraziah, A., and Abd Alla A.N. Am. J. App. Sci. 6 (2009) 1653.

[8] Kiinkenberg, G., J. Dairy Sci. 84 (2001) 1118.

[9] Prazeres, J.N., Cruz, J.A., Pastore, and G.M. Braz. J. Micro. 37 (2006) 505

[10] Kumar, S., Dwevedi, A., and Kayastha, A.M., J. Mol. Catal. B: Enzymatic 58 (2009) 138.

[11] Wang, Y., Srivastava, K.C., Shen, G.J., and Wang, H.Y., J. Ferment. Bioeng. 79 (1995) 433.

[12] Takahashi, T., Takayama, K., Machida, Y., and Nagai, T., Int. J. Pharm. 61 (1990) 35.

[13] Cardenas, A., Monal, W.A., Goycoolea, F.M., Ciapara,I.H., and Peniche, C., Macromol Biosci. 3 (2003) 535. 